Shramko Inna, senior lecturer of Information Systems and Technologies Department, Dnipro State Agrarian and Economic University, Dnipro, Ukraine

ORCID ID: 0000-0003-4173-6578

e-mail: shramko.i.i@dsau.dp.ua

\title{
Realities of the Use of Information Systems and Technologies in the Oilseed Cultivation in Ukraine
}

Abstract. Introduction: At the beginning of the XXI century, when it is impossible to determine the volume of existing information and control all information flows, it is impossible to do without information technology, which took its place in almost all spheres of human life. The term "information technology" means a set of tools and methods of information processes, including the receipt, processing, storage, transmission of information using technical and software tools. It is also evident that the use of information technology increases the productivity and efficiency of managerial work, allowing many new tasks to be solved.

The use of information technology increases productivity and in this process, many tasks are solved. Information technologies allow storing a huge amount of data, to analyze it and based on the obtained results, to offer the solution of tasks that would minimize costs and maximize profits of agricultural enterprises. The use of information technologies will significantly improve the system of information support of the agro-industrial complex of Ukraine, which will be accompanied by an increase in the competitiveness of domestic agricultural production while expanding the foreign market of oilseed processing products.

Purpose: To consider the prospects of the introduction of information technologies in agricultural enterprises of Ukraine specialized in the cultivation of basic oilseeds.

Results: The analysis of the market of the main oilseeds in the context of the regions of Ukraine was treated. The dynamics of production, area structure, and yield of the main oilseeds in Ukraine have been established. The export potential of oilseeds and their processing products has been determined. The ways of increasing the production of oilseeds based on the increase of their yield and bringing it to the world average are analyzed.

The article discusses the principles of natural agro-production that rely on an automated decision support system. There was analyzed geoinformation technology, which is based on precision agriculture. Information technologies used for sunflower, winter rape, and colza and soybean cultivation are considered. The newest information technologies for effective management of agricultural enterprises of Ukraine are offered. John Deere's major software products have been researched, as their technology accounts for about $30 \%$ of all agrarian technology available.

Conclusions: Analyzing the data of the State Statistics Committee of Ukraine, the tendency of increasing acreage under oilseeds during 2014-2018 was revealed. This is due to the steady increase in demand for oil products in the world market. Due to the rather low yield of oilseeds, Ukraine loses about 15\% of its yields on average. To increase yields without adversely affecting the environmental quality of products and environmental degradation, the latest information technologies should be introduced into agricultural production. The introduction of DSS will synthesize unique agricultural technologies that will optimize the process of growing oilseeds. The implementation of GPS monitoring in agricultural production will lead to complete control over the condition and use of agricultural machinery, which will result in savings of 20-30\% of fuel and lubricants and increase of yield by an average of $10 \%$.

Keywords: information; information technology; agrarian production; oil crops.

удк 631.15:004.9:004.77

Шрамко I. I., старший викладач кафедри Інформаційних систем і технологій Дніпровського державного аграрно-економічного університету

\section{Реалії використання інформаційних систем і технологій при вирощуванні олійних культур в Україні}

На початку ХХІ століття, коли визначити об'єми існуючої інформації і контролювати усі інформаційні потоки неможливо, вже не можна обійтися без інформаційних технологій, які зайняли своє місце практично в усіх сферах життя людини. Під поняттям «інформаційні технологї̈ розуміють сукупність засобів $i$ методів інформаційних процесів, зокрема отримання, обробки, зберігання, передачі інформації з використанням технічних $i$ програмних засобів. Очевидним також є те, що застосування інформаційних технологій підвищує продуктивність й ефективність управлінської праці, дозволяючи по-новому вирішувати багато завдань.

Проведено аналіз ринку основних олійних культур в розрізі регіонів України. Встановлено динаміку виробництва, структуру площ та урожайності основних олійних культур в Україні. Визначено експортний потенціал олійних рослин та продуктів їх переробки. Проаналізовано шляхи підвищення виробництва олійних культур на основі збільшення їх врожайності та доведення ї̈ до середніх світових показників.

В статті розглянуто принципи природного агровиробництва, які спираються на автоматизовану систему підтримки прийняття рішень. Проаналізовано геоінформаційні технології на які спирається точне землеробство. Розглянуті інформаційні технології що застосовуються при вирощування соняшнику, ріпаку озимого і кользи та сої. 
Запропоновані новітні інформаційні технології для ефективного управління аграрними підприємствами України. Досліджено основні програмні продукти компанії John Deеге, оскільки їх техніка займає близько 30 \% від усієї техніки наявної в розпорядженні аграріїв. Через досить низький рівень врожайності олійних культур Україна в середньому втрачає близько 15\% врожаїв. Для підвищення врожайності без негативного впливу на екологічну якість продукції та погіршення стану навколишнього середовища слід впроваджувати в аграрне виробнищтво новітні інформаційні технології. Впровадження СППР дозволить синтезувати унікальні агротехнології, які дозволять оптимізувати процес вирощування олійних культур. Впровадження в аграрному виробництві GPS моніторингу приведе до повного контролю за станом та використанням сільськогосподарської техніки, що приведе до економії на 20-30\% паливно-мастильних матеріалів та збільшення врожайності в середньому на 10\%.

Ключові слова: інформація; інформаційні технологї; аграрне виробництво; олійні культури.

Formulation of the problem. The practical solution of the problems related to the need to ensure the effective functioning of the agricultural enterprise depends first of all on the degree of mastering of methods of information and strategic information in the management of the agricultural activity. Based on strategic information management decisions are made, which determine the original plan of development and effective functioning of the agricultural enterprise. World practice indicates that $2 / 3$ of the increase in agricultural production is related to the introduction of the latest advanced information technologies. Today, the innovative potential of Ukraine's agro-industrial complex is used within 4-5\%, compared to $50 \%$ in the USA, so the aspects of the comprehensive introduction of information technologies in the agricultural production of Ukraine need further research.

Analysis of recent research and publications. Problems and aspects of the introduction of information technologies in agricultural production of Ukraine were explored by agrarian economists such as N. Vasiliev $[1,4]$, O. Datsiy [5], M. Kropyvko [10], P. Sabluk [16] and others. I. Devets [6], V. Babenko [3] and others have devoted their attention to identifying problems of using information technologies in the activities of agricultural enterprises of Ukraine. At the same time, the issue of introduction of information technologies into the activities of agricultural enterprises of Ukraine, which specialize in the cultivation of sunflower, rapeseed, and soybeans, requires further research.

Formulation of research goals. To consider the prospects of the introduction of information technologies in agricultural enterprises of Ukraine specialized in the cultivation of basic oilseeds.

Presentation of the main research material. Demand for oil products has increased significantly in recent decades. Ukraine has a leading position in the world in the export of oilseeds and their products. According to the National Science Center of the Institute of Agrarian Economics, in January-September 2018, Ukraine exported oilseeds for about UAH 37813 million, which is $3 \%$ more than in the corresponding period of 2017. Rape is the leading exporter of this group. It exported 1.7 million tons worth about UAH 19711 million. Exports of more than 1.5 million tons of soybeans brought in about UAH 16944 million. Agrarians also exported 25.000 tons of sunflower seeds for about UAH 367 million [11].

Table 1 Dynamics of the structure of acreage of the main oilseeds of Ukraine, thousand hectares

\begin{tabular}{|c|c|c|c|c|c|}
\hline \multirow{2}{*}{$\begin{array}{c}\text { Sown area of } \\
\text { the }\end{array}$} & 2014 & 2015 & 2016 & 2017 & 2018 \\
\cline { 2 - 6 } & 5257 & 5105 & 6073 & 6034 & 6058 \\
\hline $\begin{array}{c}\text { Sunflower } \\
\text { Rapeseed }\end{array}$ & 1806 & 682 & 455 & 789 & 1042 \\
\hline Soybean & 882 & 2158 & 1869 & 2000 & 1709 \\
\hline
\end{tabular}

Source: Compiled by the State Statistics Service of Ukraine [11]

The analysis of the structure of sown areas during 2014-2018 revealed an increase in the areas of sunflower, winter rape, and colza. Thus, in 2014, the sunflower area amounted to 5257 thousand hectares, rapeseed, and colza -1806 thousand hectares, soybeans -882 thousand hectares, and in 2018 they amounted to 6058 thousand hectares, 1042 thousand hectares and 1709 thousand hectares, respectively. Sunflower crops increased 1.1 times, soybeans 1.9 times. This increase is driven by a steady increase in demand for processing products from these crops. The area under rapeseed and colza has decreased by 764 thousand hectares, which is caused by the peculiarities of agro-technological methods of cultivation of this crop and a record fall in world prices for these products.
In the analysis of the structure of sown areas in the context of the regions of Ukraine, the leaders in the production of basic oilseeds in 2018 were: by sunflower Dnipropetrovs'k region (592.7 thousand hectares), rapeseed and colza - Odessa region (150.5 thousand hectares) and Poltava region on soybeans (178.5 thousand ha). Dnipropetrovs'k region in the rating of regions of Ukraine among the producers of oilseeds by area of sowing in 2018 took 1 position on sunflower (592,7 thousand hectares), 2 positions on winter rape and colza ( 86.5 thousand hectares) and only 22 positions on soybean $(3,5$ thousand ha).

Analyzing the production of basic oilseeds in Ukraine, we can conclude that the volume of sunflower production in 2018 increased by 1.3 times in comparison with 2014, winter rapeseed and colza by 1.2 times, soybeans by 1.1 
times and amount to 14165,1 thousand tons, 2750.6 thousand tons and 4460.7 thousand tons respectively. In particular, in terms of individual regions of Ukraine in 2014, the leaders were: Kirovograd region for the production of sunflower with 1165.5 thousand tons with a yield of 21.4 centners / ha, Odessa region in the production of winter rape and colza with 251.7 thousand tons with a yield of $20.9 \mathrm{c} / \mathrm{ha}$ and the Kiev region for the production of soybeans with 414.9 thousand tons with a yield of $21.9 \mathrm{c} / \mathrm{ha}$. The best yields in 2014 were: for sunflower in Cherkasy region $-28.8 \mathrm{c} / \mathrm{ha}$, for rapeseed in Rivne region - 34.8 c / ha and for soybeans in Trans Carpathian region - 39.8 c / ha. In 2014, the Dnipropetrovsk region ranked 3rd in sunflower rank, 9th in winter rape and colza, and only 22 in soybean. In 2015, the Dnipropetrovsk region took the lead on sunflower production with 11.98 thousand tons of harvested yield with a yield of $22.4 \mathrm{c} / \mathrm{ha}$. The Khmelnytsky region was the leader in the production of winter rape and colza with 223.5 thousand tons with a yield of 32.8 centners/ha and on soybeans - 497.3 thousand tons with a yield of 18.7 centners/ha. Dnipropetrovs'k region took the production of winter and colza rape and soybeans 9 and 22 positions respectively. In the production of basic oilseeds in 2016 the leaders were: Kharkiv region with 1352.2 thousand tons with a yield of 27.8 centners / ha on sunflower, Khmelnytsky region with 124.1 thousand tons with a yield of 27.1 centners / ha on winter rape and colza, Poltava region with 496 thousand tons with a yield of 23.8 c / ha on soybeans. The Dnipropetrovs'k region occupied 3, 6 and 22 positions on sunflower, winter rape and colza, as well as soybeans, respectively. Analyzing the statistical data for 2017, it was found that Dnipropetrovs'k oblast took the lead among the regions of Ukraine in the production of sunflower with 1202.8 thousand tons with a yield of $19.2 \mathrm{c} / \mathrm{ha}$, on winter rape and colza the first place was taken by the Odessa region with 260.9 thousand tons with a yield of $23.4 \mathrm{c} / \mathrm{ha}$, soybeans Khmelnytsky region with 471.9 thousand tons with a yield of $24.7 \mathrm{c} / \mathrm{ha}$. For the production of winter rape and colza and soybeans, Dnipropetrovs'k region took the 7th and 2nd positions, respectively. The year 2018 is marked by a dramatic change in leaders in oilseed production. The first place in the production of sunflower took the Kharkiv region with 1468.2 thousand tons with a yield of $27.8 \mathrm{c} /$ ha, on winter rape and colza - Vinnytsia region with 240.5 thousand tons with a yield of $30.6 \mathrm{c} / \mathrm{ha}$ and on soybeans - Poltava area with 409.5 thousand tons of yield of $22.9 \mathrm{c} / \mathrm{ha}$. The Dnipropetrovs'k region traditionally holds the 3rd position on sunflower, the 6th position on winter rapeseed and colza and the 22nd position on soybeans. Such steadily low soybean production figures in Dnipropetrovs'k region are related to the soil and climatic conditions of the region. Our region is not included in the soybean belt of the Forest Steppe of Ukraine. Most of the region belongs to the steppe zone, which reduces the possibility of soybean cultivation [11, 17, p. 363].
In 2014 , the levels of marketability and profitability were 76 and $36.5 \%$, respectively. In 2015, the level of profitability reached $80.5 \%$, which was made possible by the level of marketability of $74 \%$ and the increase in the price of sunflower seeds (market value of 11.18 million tons amounted to 84.65 billion $\mathrm{UAH}$, the cost of growing 29.98 billion UAH). In 2017, the level of profitability decreased to $41.3 \%$ (at a market value of seeds of 106 billion UAH), this fact was associated with a fall in the level of marketability to $61 \%$ and an increase in the cost of cultivation (more than 50 billion UAH). In 2014, at a market level of $63 \%$, the profitability level of soybean production was $34.5 \%$, which was due to higher purchase prices in the market that were 1.62 times higher than the costs incurred. This positive trend was observed in 2015 as well - the profitability level reached $38.6 \%$ with the market level of $89 \%$ (costs were $67 \%$ of the selling price). The best performance was achieved in 2016 - the profitability level reached $52 \%$ with the market level reduced to $67 \%$. In 2017 , there was a significant decrease in the level of profitability, which amounted to $28.8 \%$. In 2014 , the profitability of rapeseed and colza cultivation was $29.2 \%$, while the marketability of $87 \%$. In the period 2015-2017, the level of profitability fluctuated in the range of $43.6-45 \%$ at the level of marketability of $87-90 \%$. This tendency was achieved due to the annual increase in the purchase price [9].

According to the data of the United Nations Food and Agriculture Organization (FAO) in 2017, the average yield among the world leaders of agricultural production is $21.1 \mathrm{c} /$ ha in sunflower seeds, in rape $-24.7 \mathrm{c} / \mathrm{ha}$ and in soybeans - $27.6 \mathrm{c} / \mathrm{ha}$. The corresponding indicators for Ukraine for 2017 are respectively 20.2 c / ha, 27.9 c / ha and $19.7 \mathrm{c} / \mathrm{ha}$ [14]. Due to the rather low level of yield, Ukraine on average loses about $15 \%$ of yields [18, p.117].

Increasing the productivity of oilseeds in Ukraine is carried out by the application of a large number of organic and mineral fertilizers, the use of pesticides and herbicides, the complex structure of complex mechanization, intensive technologies, cultivation of highyielding varieties of crops and more. However, these methods of increasing yields can adversely affect the ecological quality of the cultivated produce and impair the overall state of the environment [7].

According to the co-founder of the All-Ukrainian public organization "Organic Farming Club" M. Trofymenko the main component of natural agro-production should be all operations of cultivation of the soil with the achievement of the maximum effect of soil restoration. The process of generating agro-technological solutions in agronomy involves the collection of heterogeneous data and knowledge, their analysis and formalization, as well as obtaining based on the accumulated information of agrotechnological differentiated decisions, including the implementation of agro-techniques. It is the synthesis of optimal agro-technology that is the main goal of the decision support system (DSS). Decision Support Systems (DSS) refers to a new generation of information systems 
whose primary purpose is to provide computer-aided decision-making on poorly-structured and unstructured organizational management issues at various stages of decision-making. Different methods are used to analyze and develop proposals in the DSS. These can be: information search, data mining, database searching, simulation modeling, situational analysis, etc. [15, p.125]

In the framework of the introduction of information technologies in the agricultural production of Ukraine based on the Kyiv Institute of Cybernetics V. Glushkov developed specialized DSS "Agrotech" and "Zootech". AgroTech SPD provides a methodology that allows identifying the model clearly, determining its priority interactions with other models, types, and extent of the impact, all possible cases of activation of the model. This DSS includes more than 280 tables of economic and market relations, farming systems, cartography, process management, the environment and more. The easiest way to predict different moments of a management process is to use application software, namely spreadsheet processors. [8, p. 23].

Automation, complex mechanization, and development of information technologies, which allow receiving from each unit of used resources more quality and variety of high-quality foodstuffs - is the most effective way of development of the agro-industrial complex. The use of the latest information technologies enables the sustainable development of agriculture. Named "precision farming", this management system is based on the latest developments in global positioning systems (GPS) and geo-information technology. To implement precision farming technology requires modern on-board computer-controlled agricultural machinery, technical tools - automatic samplers, various sensing and measuring complexes, automatic harvesting machines, remote sensing devices, as well as multifunctional software that allows for optimal reception decision when managing an agricultural enterprise [2, p. 148].

The global positioning system is based on the radiolocation system using the signals of the navigation satellites. The introduction of GPS monitoring system in the agricultural production of Ukraine makes it possible to eliminate the inappropriate use of agricultural machinery, will allow controlling the state of the equipment in realtime, which allows reducing downtime for ongoing repairs, accurately record the treated area and fuel costs, etc. According to various experts and some calculations, the savings of fuel and lubricants when equipping the tractor fleet with satellite monitoring systems reaches 20 $30 \%$.

One example of GPS monitoring is the Teletrack-AGRO agricultural transport control system, which can be integrated with accounting software. This system allows reducing fuel and lubricant costs and depreciation costs, to minimize losses during harvesting and transportation, to obtain reliable data on performed agricultural operations and to increase efficiency in growing oilseeds due to optimal planning of agricultural machinery movement.

About $30 \%$ of agricultural enterprises in Ukraine own by John Deere machinery. This company has developed a series of i-solutions consisting of a set of integrated electronic control systems to maintain a high level of efficiency of agricultural work in the automatic mode. All i-solution components are integrated into a single GreenStar system and work with both the StarFire 3000 receiver and the GreenStar system displays to allow full monitoring and control of all i-components. Examples of these solutions include: Parallel Tracking - a satellite parallel driving system, AutoTrac - a hands-free satellite automatic control system, iTECPro - a system that not only automates straight field passes, but also automates reversals, HarvestMonitor - crop mapping system, FieldDoc - a system that will automatically record data on all field operations and others. Particular attention should be paid to the JDLink system, which allows the integrated processing of accepted data on the state of agricultural machinery. This system allows obtaining information on the location of technology, technological operations (per minute), monitoring and safety system messages and data on the operating parameters of the machine, such as fuel consumption, downtime, and relocations [14]. The use of machinery with controls of precision farming will increase the yield of oilseed crops by an average of $10 \%$.

Today, geoinformation technologies in Ukraine are still considered innovative. It is promising to develop software for transparency of land cadastre, implementation of precision farming practices with the use of geoinformation systems, the use of unmanned aerial vehicles, raising the level of knowledge of agrarians in ITinnovation issues, development of the internal technology market in the agro-industrial complex. Geoinformation system (GIS), integrated in the DSS, allows to analyze and visualize the reference data related to coordinates using GPS receivers (field contours, distribution of maps by agrochemical, agro-physical and agronomic parameters, field history, yield of maps, etc.), as well as to create card files for agricultural machinery equipped with on-board computers and GPS receivers, to differentiate agricultural operations, taking into account the location of machinery on the field.

The Research Institute of Engineering, Energy, and Informatics of AIC has presented in 2016 the project "Creation of geoinformation decision support services in the agrarian and industrial complex for state and local authorities" (supervisor - V. Khilenko). It elaborates approaches to the classification of crops and the estimation of acreage based on satellite images, as well as the implementation of the proposed approaches using modern GIS platforms in the form of geoservice on the NULES portal of Ukraine (geoport.nubip.edu.ua). The results of the study allow monitoring of land and acreage at different levels.

Conclusion. The use of information technology increases the productivity and efficiency of managerial 
work, allowing many new tasks to be solved. Information technologies allow storing a huge amount of data, to analyze it and based on the obtained results, to offer the solution of tasks that would minimize costs and maximize profits of agricultural enterprises. The use of information technologies will significantly improve the system of information support of the agro-industrial complex of
Ukraine, which will be accompanied by an increase in the competitiveness of domestic agricultural production while expanding the foreign market of oilseed processing products. Future research will consider the use of the latest information technology for the automation of farm management in Ukraine.

\section{References:}

1. Karamushka, O., Moroz, S., and Vasylieva, N. (2018) Information component of innovative support for agricultural enterprises capital. Baltic Journal of Economic Studies, 4(4), 145-151.

2. Samarets, N. \& Nuzhna, S. (2018) The modern contribution of the basic categories of producers to Ukrainian agrarian production. Agricultural and Resource Economics: International Scientific E-Journal, 4(4), 52-71.

3. Babenko, V. (2011) Informatsiine zabezpechennia vprovadzhennia ta funktsionuvannia innovatsiinykh tekhnolohii na pererobnykh pidpryiemstvakh APK. Naukovyi visnyk LNUVMBT imeni S.Z. Gzhytskoho, 13, 19-23.

4. Vasylieva, N. K. (2015). Ekonomiko-matematychne modeliuvannia v silskomu hospodarstvi. Dnipropetrovsk: Bila K.O.

5. Datsii, O. (2012). Formuvannia modeli innovatsiino aktyvnykh pidpryiemstv. Visnyk NADU, 4, 174-179.

6. Derevets, I. (2013). Informatsiino-innovatsiinyi rozvytok inzhenerno-tekhnichnoi sfery APK. Mekhanizatsiia ta elektryfikatsiia silskoho hospodarstva, 97, 300-306.

7. Dmytriieva, V. A. (2018). Tendencies in Ukrainian dynamics of crop production: effects of data set smoothing. Efektyvna ekonomika, 12. Retrieved from http://www.economy.nayka.com.ua/?op=1\&z=6758.

8. Vasylieva, N. K., Myronenko, O. A., Samarets, N. M. \& Chorna, N. O. (2017). Ekonometryka v elektronnykh tablytsiakh : navch. posibnyk. Dnipro: Bila K.O.

9. Karamushka, O. M. \& Moroz, S. I. (2018). Analiz vyrobnytstva zernovykh ta oliinykh kultur v Ukraini. Efektyvna ekonomika, 10, https://doi.org/10.32702/2307-2105-2018.10.41.

10. Kropyvko, M. M. (2018). Teoretychni zasady stratehichnoho upravlinnia rozvytkom silskohospodarskykh pidpryiemstv. Visnyk Khmelnytskoho natsionalnoho universytetu. Ekonomichni nauky, 3(2), 113-118.

11. Statistical Yearbook "Agriculture of Ukraine for 2017" (2018). In O. M. Prokopenko (Ed.). Kyiv: State Statistics Service of Ukraine (in Ukrainian). Retrieved from: http://www.ukrstat.gov.ua

12. Natsionalniy naukoviy tsentr «Instytut ahrarnoi ekonomiky». Retrieved from: http://www.iae.org.ua/

13. Prodovolcha ta silskohospodarska orhanizatsia Obiednanykh Natsii (FAO). Retrieved from: http://faostat.fao.org

14. Ofitsiinyi sait kompanii John Deer. Retrieved from: https://www.deere.com/en

15. Pavliuk, T. \& Volontyr, L. (2017). Vykorystannia suchasnykh informatsiinykh tekhnolohii v silskomu hospodarstvi. Formuvannia rynkovoi ekonomiky v Ukraini, 38, 122-127.

16. Sabluk, P., Lupenko, Yu., Mesel-Veseliak, V. \& Fedorov, M. (2014) Rezultaty i problemy reformuvannia silskoho hospodarstva Ukrain. Ekonomika APK, 7, 26-38.

17. Samarets, N. M. \& Kravets, M. O. (2018). Economic and Mathematical Analysis of Oil Crop Production. The Problems of Economy, 4, 360-370.

18. Shramko, I. I. (2015). Ekonomichnyi analiz tekhnichnoho rozvytku pryrodnoho ahrovyrobnytstva oliinykh kultur. Ekonomichnyi prostir, 101, 115-128.

Ця робота ліцензована Creative Commons Attribution 4.0 International License 